\title{
Socioeconomic and Farm-Level Effects of Genetically Modified Crops: The Case of Bt Crops in South Africa
}

Marnus Gouse

T

he year 2011 was the 14th since the first commercial release of a genetically modified (GM) crop in South Africa. In 1997/98, insectresistant $(\mathrm{Bt})$ cotton was released for production, and South Africa became the first country in Africa where a GM crop was produced on a commercial level. Bt maize was approved for commercial production in 1998/99, and Bt yellow maize was planted in the same season. The first plantings of Bt white maize in 2001/02 established South Africa as the first GM subsistence crop producer in the world. Herbicide-tolerant (HT) cotton was made available for commercial production in the 2001/02 season along with HT soybeans. Commercialization of HT maize seeds followed in 2003/04. GM cotton containing the combined or "stacked" trait (Bt and HT) was released for the 2005/06 season, and Bt/HT maize was released for the 2007/08 production season.

This chapter supplies a brief summary of the performance, socioeconomic impacts, and main issues surrounding Bt cotton and GM maize in South Africa. A substantial number of peer reviewed papers on GM crops in South Africa have been published, and it is recommended that interested readers refer to these publications for more in-depth information and discussion on the studies and findings.

\section{South African Biosafety Framework}

In 1989 a US seed company approached the South African Department of Agriculture for permission to perform contained field trials with Bt cotton. This set in motion the South African biosafety regulatory process and initiated the first trials with GM crops on the African continent. The South African Committee for Genetic Experimentation (SAGENE) had been formed in 1979 by public and private scientists to monitor and advise the National Department of Agriculture and industry on the responsible development of 
genetically modified organisms (GMOs) through the provision of guidelines and the approval of research centers and projects. SAGENE gained statutory status in 1992 as the national advisory committee on modern GM biotechnology. The approval for the commercial release of Bt cotton and maize was done under the guidelines of SAGENE for the 1997/98 and 1998/99 seasons. These guidelines and procedures remained the biosafety framework cornerstone until South Africa's GMO Act 15 of 1997 was approved by Parliament in June 1997 and entered into force in November 1999, when the regulations were published. In 1999 SAGENE was replaced by the scientific Advisory Committee that was established under the GMO Act (Wolson and Gouse 2005). The South African GMO Act 15/1997, as amended in 2006, provides a comprehensive biosafety framework to manage research, development, application, production, and trade in GMOs. The GMO Secretariat is housed in the Department of Agriculture, and decisionmaking is vested in the GMO Executive Council that represents eight government departments. The Council is advised by a national Advisory Committee of scientific experts.

Since implementation, the GMO legislation has served the country well in its balanced approach to modern biotechnology and its applications. However, more recently there have been some unclear delays in the decisionmaking process, and the scientific community and academia have expressed concern that decisionmaking has become less scientific and a lack of transparency in the process could lead to an increase in the cost of regulation and in the opportunity cost for research institutions, innovators, and in reality, consumers.

\section{Bt Cotton}

In 2007 GM cotton globally covered 15 million hectares ( 43 percent of total world cotton), of which Bt varieties accounted for 10.8 million hectares and a further 3.2 million hectares as Bt combined with a second Bt or with an herbicide-tolerance trait (James 2007). In 2009 the global GM cotton area increased to 16.2 million hectares and in 2011 to 25 million or 68 percent of global cotton plantings (James 2009, 2011). Historically, cotton has been responsible for about 25 percent of global chemical insecticides used in agriculture due to attacks by a range of insect pests (Woodburn 1995), with cotton bollworm being the main pest. In an effort to reduce insecticide use and with insect resistance build-up against chemicals, Bt technology has offered a cost-saving and environmentally friendlier alternative.

Cotton planting in South Africa declined from its peak of 180,000 hectares in 1988 (under tariff protection) to just over 5,000 hectares in 2010 due 
to a combination of market liberalization, low world cotton prices, and relatively better prices for competing crops like maize, sunflower seed, and sugar cane. South Africa has been a net importer of cotton for the past couple of decades. In 1997/98 South Africa became the first country in Africa to commercially produce GM crops with the release of Bt cotton. The initial uptake of the first Bt cotton varieties of the US cotton seed company, Delta and Pineland (D\&PL), was less than spectacular, as the conventional varieties of local ginning companies were more popular. Some commercial farmers were also cautious during the first seasons and wanted to test the new technology and see how ginners and the rest of the industry reacted. However, when the Bt gene was introduced into D\&PL's popular OPAL variety (originally from Australia), adoption increased dramatically. NuOPAL (Bt), DeltaOPAL RR (HT), and NuOPAL RR (Stacked Bt/HT), which are currently planted in South Africa, are all based on the Delta OPAL germplasm (Gouse 2009).

As clearly shown in Table 1.1, Bt cotton has been very popular, reaching 70 percent of total cotton area in 2003. The share decreased somewhat with the introduction of $\mathrm{HT}$ cotton, but $\mathrm{Bt}$ cotton remained the more popular of the two. With the introduction of stacked cotton (with both the Bt and HT events), Bt's share dropped considerably as farmers opted for cotton with both traits. By the 2005/06 season 92 percent of the cotton plantings in South Africa were GM. A large share of the conventional cotton being planted is mandatory refugia that are planted alongside Bt fields to prevent insect-resistance development. Farmers tend to plant HT cotton as refugia for stacked Bt/HT plantings.

Despite various land reform and development projects attempting to settle small-scale farmers in established and potential cotton production areas, the traditional areas of Tonga (in Kangwane Mpumalanga) and Makhathini Flats (KwaZulu-Natal) remain the major contributors to smallholder cotton production. The total number of smallholder cotton producers has varied but generally amounts to a few thousand farmers with the vast majority of them situated on the Makhathini Flats. As large-scale farmers produce the bulk of the South African cotton crop, it would not be totally correct to suggest that the adoption figures in Table 1.1 apply to smallholders as well, though Bt cotton adoption by smallholders has not been less impressive. In the first commercialization season of 1997, only 4 farmers planted demonstration Bt plots under the guidance of Monsanto (the technology owner). In 1998, 75 farmers, or 3.4 percent of the cotton farmers on Makhathini, planted Bt cotton; in 1999, 411 farmers, or 13.7 percent, planted Bt. In 2000, 1,184 cotton farmers (39.5 percent) on the Makhathini Flats planted Bt cotton. In 2001 it was 


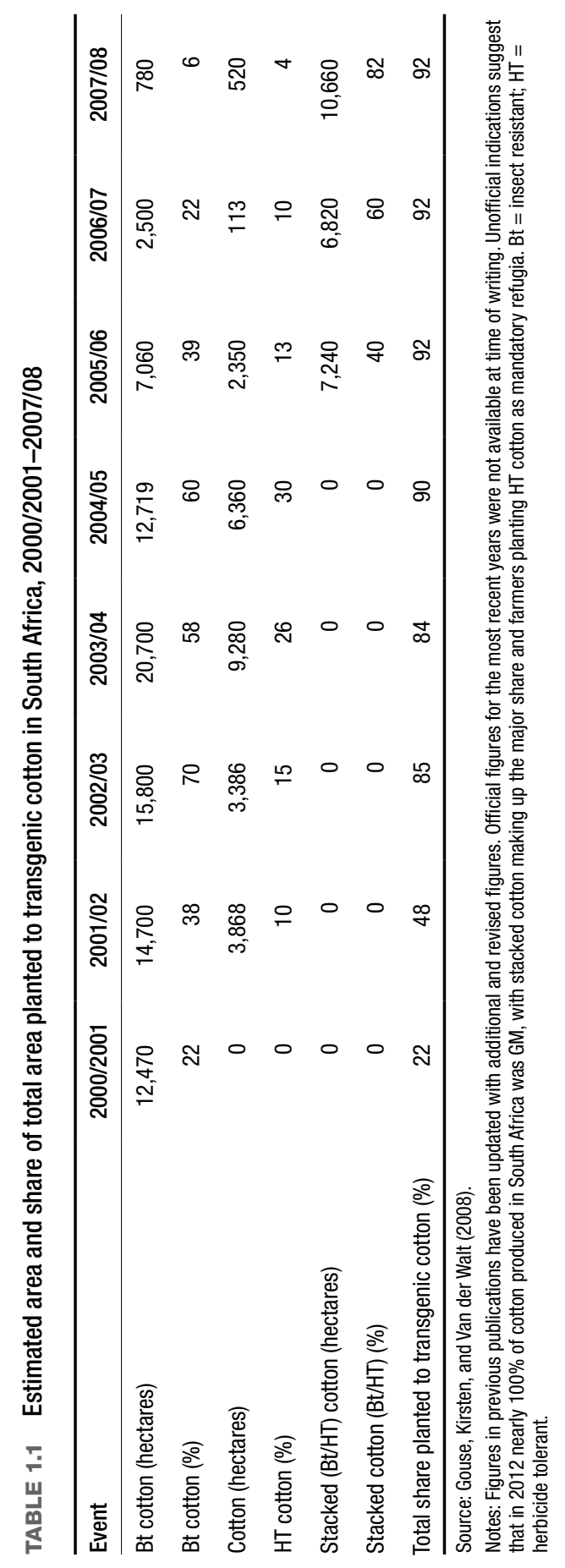


estimated that close to 3,000 of the 3,229 farmers on the Flats planted Bt, reaching close to 90 percent adoption in five years (Gouse 2009).

This remarkable adoption rate was explained partly by the impressive performance of $\mathrm{Bt}$ cotton as planted by the first adopting Makhathini farmers. However, the other major explanation was that the sole credit and input supplier and cotton buyer on the Flats, Vunisa, also noticed the performance of $\mathrm{Bt}$ cotton and started to recommend the seed to its clients/farmers. As the main objective of a cotton gin is to gin as much cotton as possible, Vunisa wanted to increase the cotton crop on the Flats but not at the expense of their credit book. After monitoring the performance of Bt cotton for the first couple of seasons, Vunisa decided that it could increase the ginable cotton crop, and decrease the risk of crop failure (due to bollworm damage) and thus their credit risk by recommending Bt cotton to farmers. It can be argued that even though Vunisa was making inputs available to farmers under credit long before $\mathrm{Bt}$ was introduced, the availability of credit and the role Vunisa's extension officers had in recommending Bt seed played a large role in smallholders' ability and decision to adopt the new technology (Gouse 2009).

All the peer reviewed publications on Bt cotton in South Africa (mainly focusing on smallholder farmers) report yield increases with the use of $\mathrm{Bt}$ cotton compared to conventional varieties (Table 1.2). Almost all studies also showed savings in insecticide expenditure; with the exception of results from the one-year, 20-farmer study by Hofs, Fok, and Vaissayre (2006). Even though most of the yield differences were substantial, some were found not to be statistically significant, mainly due to small sample sizes and large variability in the data. Compared to study results in countries like Australia, China, India, and Mexico, the relative yield gain from the use of Bt cotton in South Africa is higher. One of the reasons for this is that the base yield (nonBt cotton) of smallholders is very low, and a small change in yield is exaggerated when expressed relative to a low conventional variety yield. In fact, in some other countries, the yield advantage of Bt cotton was more than the total seed cotton yield attained per hectare in South Africa (Fok et al. 2007). Gouse, Kirsten, and Jenkins (2003) found an 18.5 percent yield increase for South African large-scale irrigation farmers for the 2000/2001 season, which compares well with a 16.8 percent increase measured on field trials at a Clark Cotton (a ginning company) experimental farm in Mpumalanga. Large-scale dryland farmers enjoyed a 14 percent yield increase, while some studies found that small-scale dryland farmers enjoyed an increase of between 23 and 85 percent over a number of seasons (Table 1.2). 


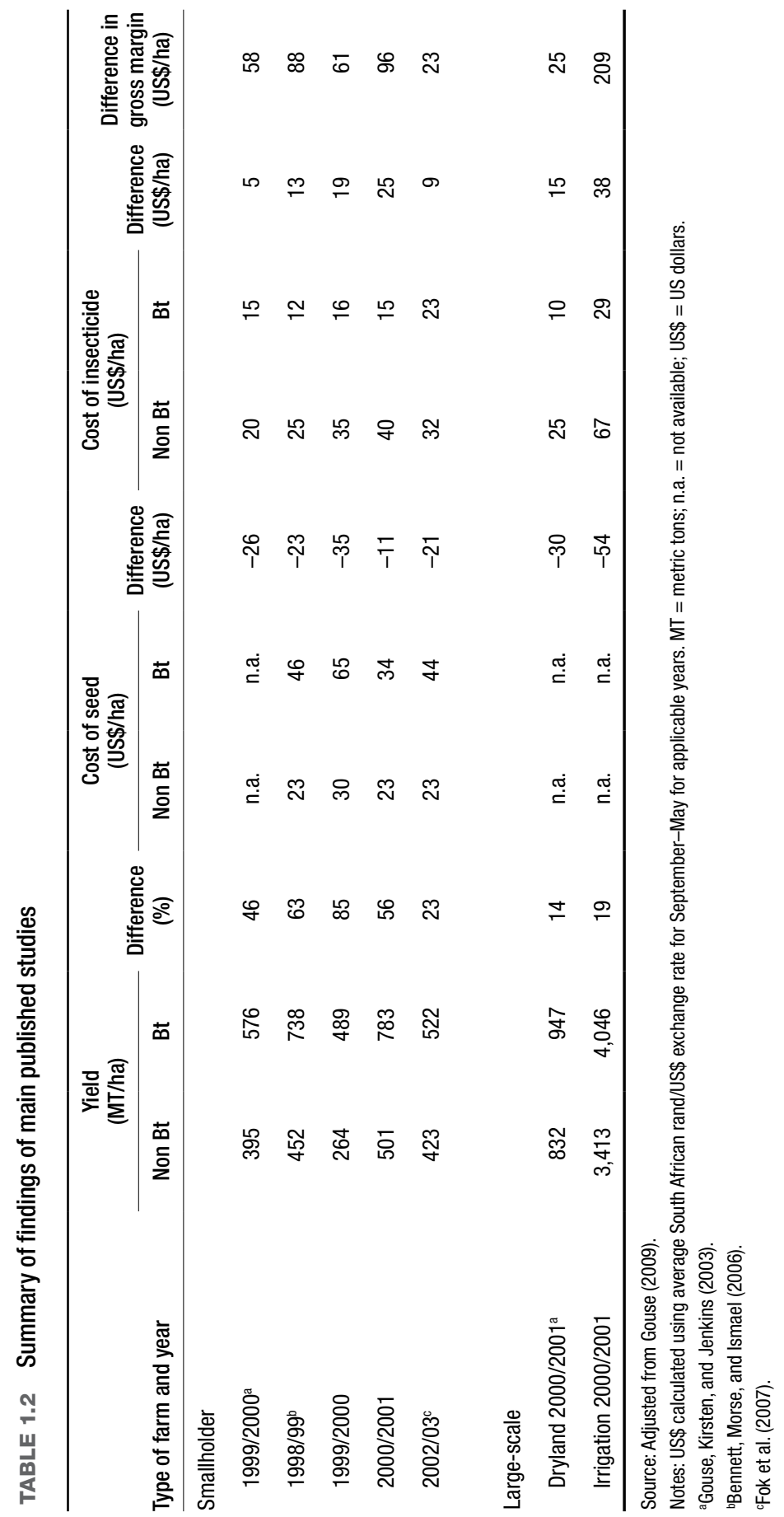


These trends are consistent with findings elsewhere, such as in Argentina (Qaim, Cap, and De Janvry 2003), where large-scale commercial farmers were reported to enjoy 19 percent yield increases and smallholder farmers reported 41 percent yield increases. Like Qaim, Cap, and De Janvry (2003), South African researchers attribute the difference between the Bt yield advantages of smalland large-scale farmers to the financial and human capital constraints that cause smallholders to invest in chemical pest control. Shankar and Thirtle (2005) showed that the average insecticide application level of smallholder farmers on the Makhathini Flats is lower than 50 percent of the optimal level; it is thus not surprising that $\mathrm{Bt}$ cotton is able to substantially reduce the yield loss caused by bollworms. With low control-group yields and limited (and in many cases ineffective) chemical insecticide applications, exaggerated yield increases in excess of 50, 60, and 80 percent as reported by Bennett, Morse, and Ismael (2006) do not seem so mind-boggling. But these results have to be seen in context, and as the authors caution, the figures might also be inflated due to selection bias.

The yield increase with Bt cotton, compared to conventional cotton, depends on the bollworm infestation level in the particular season and the effectiveness of chemical bollworm control by the farmer. It can be expected that the yield advantage will differ across farmers, farms, regions, and seasons (Fok et al. 2007). Both large-scale and smallholder farmers enjoyed significant savings on insecticides (generally $3 / 4 / 5$ pyrethroid sprays), and despite higher expenditure on seed (as a result of the additional technology fee), they enjoyed a higher gross margin. However, it is important to stress that Bt does not kill all insects, and chemical spraying is still required to prevent damage by sucking insects, which in the past have been killed in the cross-fire aimed at bollworms.

The Bt technology fee was adjusted downward by about 24 percent after the introduction season, following farmer concerns that the technology was not affordable. The fee was then held constant at South African rand (ZAR) 600 per 25 kilograms of seed (between about $\$ 50$ and $\$ 75$ according to the fluctuating local currency) ${ }^{1}$ for $1999 / 2000-2002 / 03$, at ZAR700 for 2003/04-2004/05, and then at ZAR785 from 2005/06 to the 2008/09 season. Between 1999 and 2008 a 25 kilogram bag of conventional cotton sold for between ZAR150 and ZAR430. This means that the extra Bt technology fee per 25 kilogram bag was between 1.8 and 4.0 times the price of the bag of seeds (Gouse 2009).

Analysis of "who gains?" from Bt technology showed that despite the high technology fee, farmers captured the lion's share of the additional benefits

1 All dollar amounts are US dollars. 
generated by the introduction of this new technology (Gouse, Pray, and Schimmelpfennig 2004). Basing their calculations on the abovementioned studies, Brookes and Barfoot (2010) estimated that in the 11 years from 1998 to 2008, the use of Bt cotton contributed an additional \$21 million to farm income in South Africa.

The Makhathini Flats smallholder experience with Bt cotton has been hailed internationally as the first example of how modern biotechnology can benefit resource-poor farmers in Africa. There can be no doubt that the majority of Makhathini Flats farmers did indeed benefit from the introduction of $\mathrm{Bt}$ cotton. They were able to adopt and benefit from this new technology because all the institutional structures that facilitate a functioning market were in place at the time. These structures include functioning input markets (credit, seeds, and chemicals) and output markets (seed cotton buyer) that operate at market clearing prices. An important factor was that Vunisa was the only buyer and, because of this monopsony power, could supply production credit to farmers who did not own their land, using the forthcoming crop as collateral (Gouse, Shankar, and Thirtle 2008). This system is not uncommon to Africa, where widespread failure of credit and input markets (partly due to lack of land ownership that could serve as collateral) has led to interlocked transactions, in which a firm wishing to purchase the farm output - typically a ginner in the case of cotton-provides inputs to farmers on credit and attempts to recover the credit upon purchase of the product (Tschirley, Poulton, and Boughton 2006). However, when the credit system collapsed in 2002-because of farmers defaulting on their loans as a consequence of a combination of droughts, low prices (linked to the low and stagnated world cotton price), marginal profits, adverse selection, and market competition — the whole system collapsed, and cotton production dropped.

The Makhathini smallholder experience is indeed a good example for the rest of Africa, as countries considering adoption of Bt cotton need to take note that although technical solutions can help address problems (such as lack of knowledge regarding insects and pest control, limited access to inputs, or evolution in pest pressure), no technology (GM or otherwise) can resolve the fundamental institutional challenges of smallholders and agriculture in Africa. The particular case of the Makhathini Flats and the wider story of cotton in South Africa emphasize that although all agricultural systems require adequate investment and appropriate technologies, their viability is determined by the policies and institutions that facilitate sustainable and profitable production. Bt cotton and more recently stacked (Bt/ $\mathrm{HT}$ ) varieties are still the varieties of choice for smallholder producers, but 
production levels have decreased drastically and remain limited mainly due to the relatively low price of cotton.

\section{Bt Maize}

Globally, in 2007 GM maize was planted on 35 million hectares, or 24 percent of world maize plantings, of which 9.3 million hectares was $\mathrm{Bt}$ as single trait and another 18.8 million hectares in combination with other traits (James 2007). In 2010 GM maize covered 46.8 million hectares globally, and the area increased to 51 million hectares in 2011 (James 2010, 2011). Bt maize was first introduced in the United States in 1996, and by 2006 it covered 40 percent or 12.7 million hectares of the total US maize crop. In Argentina, varieties containing the Bt trait were planted on 73 percent of the total Argentinean maize area, and in Spain it covered 54,000 hectares or 15 percent of the total maize area (Brookes and Barfoot 2008).

Maize is the most important field crop in South Africa and annually covers an estimated 30 percent of the total arable land. Maize serves as staple food for the majority of the South African population and also as the main feedgrain for livestock. Between 60 and 70 percent of the South African yellow maize production is consumed in the chicken-production sector. Over the past 9-10 years, South Africa produced an average of 9.3 million metric tons of maize on 2.75 million hectares.

Even though Bt yellow maize was released in 1998 for commercial production, GM white maize was commercialized only in 2001. That year, South Africa became the first country in the world to permit the commercial production of a GM subsistence crop-Bt white maize. In South Africa and other southern African countries, the losses sustained in maize crops due to damage caused by the African maize stem (stalk) borer (Busseola fusca) are estimated to be between 5 and 75 percent, and it is generally accepted that, pre-Bt, Busseola annually reduced the South African maize crop by an average of 10 percent (Annecke and Moran 1982). Gouse et al. (2005) showed that in 2005 with a seemingly conservative estimate of 10 percent for damage caused by both Busseola fusca and Chilo partellus, the average annual loss (in the absence of $\mathrm{Bt}$ ) adds up to just under a million tons of maize, with an approximate value of ZAR810 million. At the 2008 maize price level (more or less similar to the 2011 price level), the potential damage caused by borers would be closer to ZAR1.6 billion (about $\$ 200$ million). Both B. fusca and C. partellus can be controlled to a satisfactory level with the use of the $B t$ gene currently used in South African Bt varieties (Cryl Ac). 
As can be seen in Table 1.3, the initial spread of Bt maize was quite slow because of the scale-up time required to have a sufficient amount of seeds and to have the Bt trait inserted in hybrids that were suitably adapted to local conditions. Approval for commercial release of herbicide tolerance came in 2002 and the stacked traits of Bt and HT in 2007. Compared to cotton, the decrease in Bt and HT maize since the introduction of stacked maize was less pronounced. Bt remains the most popular trait, partly because especially white stacked maize adoption has been hindered by inadequate seed availability. In the 2008/09 production season, GM maize covered 70 percent of the total South African maize area, with Bt maize covering 43 percent. In 2009/10 the Bt maize area increased by a further 269,000 hectares up to 48 percent, mainly stemming from a drop in the white stacked maize area because of inadequate seed supply.

Considering the adoption rates illustrated in Table 1.3, it is possible to conclude that South African maize farmers have benefited from the introduction of GM maize. Similar to the indicated GM cotton adoption rates in Table 1.1, these GM maize adoption rates represent adoption by predominantly commercial farmers. There are no official smallholder GM maize adoption figures, but it is estimated that about 10,500 subsistence, smallholder, and emergent farmers (about 23 percent of the smaller farmers), buying hybrid seed from the three major seed companies, planted GM maize in 2007 (Gouse, Kirsten, and Van der Walt 2008). However, there are still areas in South Africa where smallholders plant mainly open-pollinated varieties and traditional/saved seed, and definitions of subsistence, smallholder, smallholder projects, and emerging farmers also complicate estimations. It can therefore be argued that the number of smallholders planting GM maize is still relatively minimal.

Marra, Pardey, and Alston (2002) found that there were significant benefits to planting Bt maize in the United States through increased yields, even when it appeared as if borer infestation levels were not large enough to control with insecticides. Marra, Carlson, and Hubbell (1998) reported that the use of Bt maize boosted yields by $4-8$ percent, depending on location and year. Results from outside the United States show a similar pattern. In the Huesca region in Spain, Brookes (2002) reported a yield increase of 10 percent over conventional maize protected with pesticides and an increase of 15 percent when insecticides were not used. Other regions in Spain enjoyed an average $\mathrm{Bt}$ yield advantage of 6.3 percent, with a range of $2.9-12.9$ percent. James (2002) reported a 8-10 percent yield increase in Argentina up to 2004, and more recent studies show a 5-6 percent increase (Brookes and Barfoot 2008). Gonzales (2002) recorded a yield advantage of 41 percent for Bt maize on 


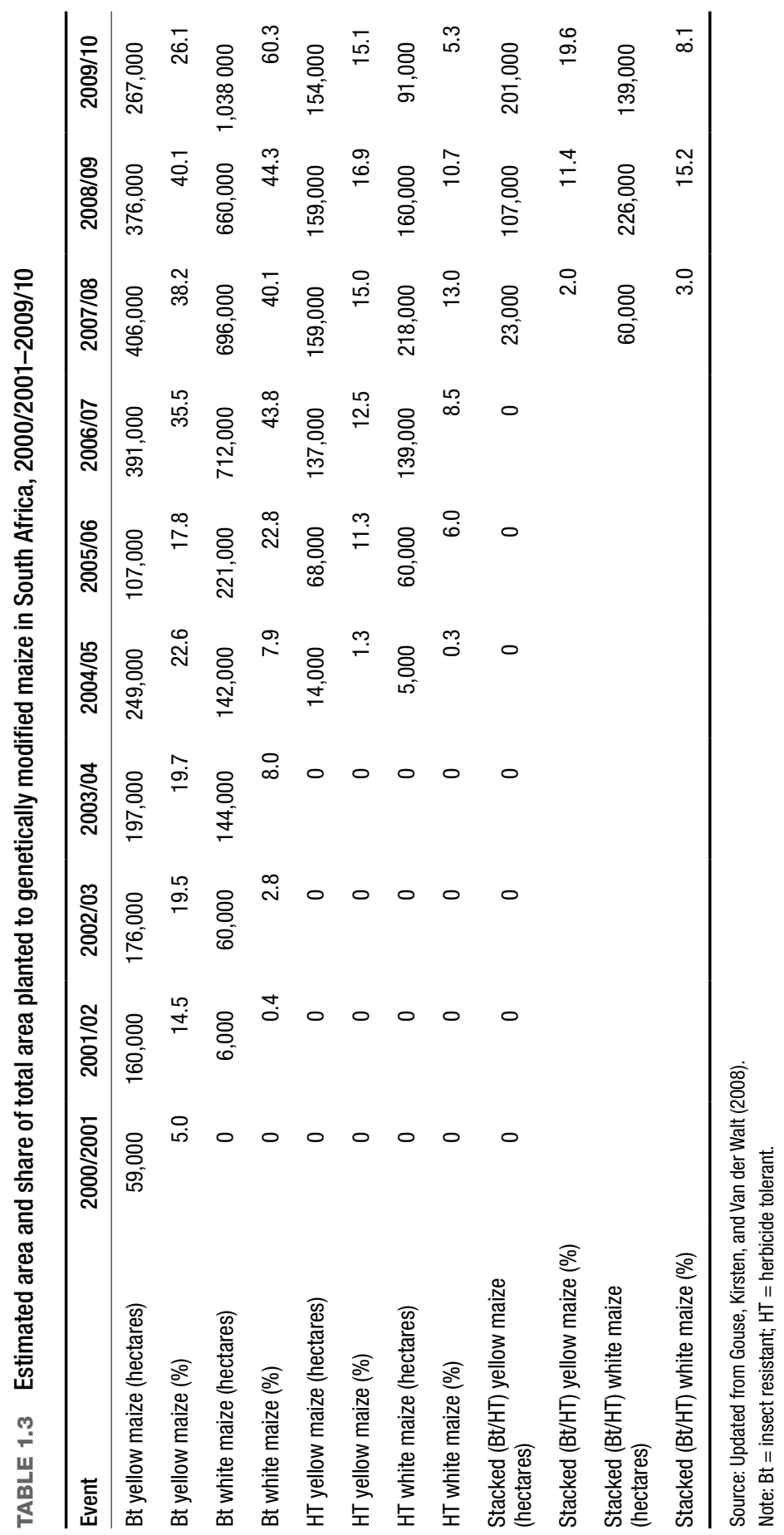


field trials in the Philippines, and Philippine farmers indicated an even higher (60 percent) yield improvement. In most countries, the additional cost of the Bt technology has exceeded the savings on insecticides and thus has resulted in an increase in total production costs.

Compared to the number of studies and publications on Bt cotton in South Africa, the body of literature and the number of researchers following the farm-level impacts of Bt maize in South Africa is rather limited. Even though there have been reports in the media quoting some anecdotal findings of some fairly unscientific studies, only a series of studies by the University of Pretoria ${ }^{2}$ have endeavored to follow the socioeconomic effects and performance of Bt maize for a number of seasons, mainly focusing on smallholders.

Gouse et al. (2005) found average yield increases (due to better stem borer control) of 10-11 percent for commercial (dryland and irrigation) farmers, whereas smallholder $\mathrm{Bt}$ adopters reported yield increases of $0-32$ percent for the seven seasons 2001/02-2007/08 (Gouse et al. 2010). A statistically insignificant average yield increase of 12 percent was found across the seven seasons. In seasons with a low stem borer infestation, resulting in insignificant stalk borer damage, farmers planting Bt maize seed were in all likelihood worse off than farmers planting conventional hybrid maize because of the extra Bt technology fee. It is however difficult to make preplanting predictions on seasonal stalk borer infestation levels due to the complicated relationship between rainfall, variable seasons, growth of maize, effect of stalk borer on the maize plant, and the effect of natural enemies on the host (Annecke and Moran 1982). Because a dry early season does not necessarily portend a dry season throughout, South African largescale commercial farmers indicate that Bt serves as affordable insurance against unforeseeable stalk borer outbreaks, but increases in seed cost or technology fees could easily outstrip that insurance value to small-scale and subsistence farmers in South Africa (Gouse et al. 2006).

Gouse et al. (2006) endeavored to quantify the 16 percent yield increase, the average of the Bt yield advantage for two groups of farmers in northern KwaZulu-Natal for the 2002/03 season, in subsistence-farmer terms. For these smallholders a 16 percent yield increase meant only 110 kilograms of extra grain, and selling the extra grain would render a rather insignificant income advantage. However, arguing that the extra grain replaces potentially purchased, relatively more expensive, maize meal (flour), the yield

2 Mainly supported by the Rockefeller Foundation and the Economic and Social Research Council/ Department for International Development funding and in collaboration with, among others, Rutgers University, Imperial College, and the Programme on Mycotoxins and Experimental Carcinogenesis at the South African Medical Research Council. 
advantage seems more valuable. Alternatively, using a generally excepted ruleof-thumb stating that a rural household of seven members requires fourteen 80 kilogram bags of maize meal for a year to be food secure, the 16 percent yield advantage in 2002/03 resulted in approximately 36 more days of maize meal for the household. This is assuming, rather unrealistically, that there is no postharvest damage to harvested grain.

Insecticide use by maize-producing smallholders is limited, and $\mathrm{Bt}$ adoption consequently did not result in substantial insecticide savings. $\mathrm{Bt}$ adoption by commercial farmers has resulted in decreased expenditure on insecticides but, similar to what has been reported in other countries, generally not enough to cover the increased seed cost. Depending on the quantity of seed purchased, Bt maize seed was 23-25 percent more expensive than conventional seed, and more recently those percentages have increased to about $27-30$ percent.

Following the planting of HT maize demonstration plots in 2003/04 and 2004/05 in some smallholder areas where Bt had been introduced, a number of farmers adopted HT maize in 2005/06. Many farmers who planted Bt maize in previous years instead opted for HT seed (Gouse et al. 2010). Farmers indicated that compared to stem borers, weeds are a constant pest, and it would seem as if the labor-saving benefit of HT maize is valued higher than the insect control (yield) benefit of $\mathrm{Bt}$. With a substantial share of the economically active, able-bodied population emigrating to urban areas in search of employment and a tragically high HIV/AIDS prevalence, especially in rural KwaZulu-Natal, labor has become a scarce commodity for many South African smallholder farmers. By using broad-spectrum herbicides before and after planting (some only after), as opposed to manual weeding with hand and hoe, farmers are able to save quite considerably on family labor person-days. For some of the seasons, HT maize also yielded more grain than conventional hybrid maize with manual weeding because of more effective weed control. In some areas in KwaZulu-Natal, HT has totally replaced Bt. In an attempt to benefit from both the GM technologies, some smallholders purchased stacked $\mathrm{Bt} / \mathrm{HT}$ maize, but others indicated this maize is too expensive and opted for HT only (Gouse et al. 2010). Stem borer pressure has been low during the study seasons, and it would be interesting to see how HT-adopting farmers react to possible higher borer levels in seasons to come.

Using yield increase, insecticide savings, and increased seed expenditure indications of mainly Gouse et al. (2005), Brookes and Barfoot (2010) estimated that between 2000 and 2008, Bt maize adoption increased adopting farmers' farm income by a total of $\$ 476$ million. That is a productivity 
increase-induced injection into the economy of ZAR3.67 billion over 9 years. To put this amount into context, over the past 10 years the South African Government has, through the platforms and initiatives created under the National Biotechnology Strategy (Republic of South Africa, Department of Science and Technology 2001), invested about ZAR900 million (Hanekom 2010) in biotechnology research and development.

\section{Conclusion}

Benefiting from a strong research background, South Africa was able to proactively develop guidelines and later legislation and regulations on the development and use of modern biotechnology and its applications such as GM crops. Development and implementation of a relatively dynamic GMO legislation and underlying regulations have enabled South African farmers - and, to a lesser extent, consumers, through maize meal prices and health aspects (see Chapter 2) - to benefit from the first wave of GM crops.

Solely based on the high adoption levels of especially Bt cotton and maize by large-scale farmers, in the presence of available and less-expensive conventional seed varieties (including near isolines), it is possible to conclude that farmers benefited. Some peer-reviewed studies have shown that like largescale farmers, smallholder cotton and maize farmers have also benefited, mainly through savings on insecticide applications and limitation of the damage caused by bollworms and stem borers.

Whereas Bt cotton saw a near 100 percent smallholder adoption rate in only a couple of years, adoption of $\mathrm{Bt}$ maize has been limited. There are a number of reasons for this: in a vertically integrated production system where the input supplier also ensures an output market, adoption of a (early season) more expensive but productivity-increasing technology makes sense. However, smallholder maize farmers have to fund production inputs, and as many only produce on a subsistence level (in many cases surplus production depends on the season's rainfall), farmers are unable to directly recover their input expenditures. Contrary to cotton, for which bollworm pressure and damage seems to be more constant and severe, stem borer infestation levels (especially on dryland maize) vary significantly from season to season and across areas, and the damage level is generally lower than with cotton. Though very few smallholder maize farmers apply an insecticide to control stem borers on maize, the amount of labor and chemicals required to control borers is far less than what is required to control bollworms on cotton. Another factor that is sometimes not taken into consideration, especially in the South African context, is that smallholder maize farmers' reasons 
or motivation for maize production differ. In the production of a cash crop like cotton, farmers are profit driven and are intent on producing as much as possible. On the contrary, some smallholder maize farmers are only interested in producing enough for their households, others only plant a couple of lines for fresh maize, and yet others only produce to sell. It is unlikely that the smaller producers would invest in a productivity-increasing technology like Bt maize.

That a technology was introduced and adopted and that farmers benefited does not necessarily result in a flourishing sector, as is evident from the example of South African cotton. Even with biotechnology, South African cotton farmers were not able to produce profitably at low cotton world prices. The fact that many smallholders continued producing, while commercial farmers left the sector for greener or more profitable pastures is indicative of smallholders' dependence on government support and limited alternative production options and not of the success of biotechnology.

Bt seed technology is a production tool just like fertilizers, herbicides, or irrigation technologies. Contrary to the technologies of the Green Revolution, it might be able to improve the yields of farmers with limited ability or means to control insects. However, it will by no means be able to overcome institutional failure and governance challenges that seem to be endemic in African agriculture and that were also the limiting factors in the Green Revolution. The experience with Bt cotton on the Makhathini Flats emphasizes that technology-induced advances might be short lived in the absence of the correct institutional structures, regulations, cooperation, and competition.

\section{References}

Annecke, D. P., and V. C. Moran. 1982. Insects and Mites of Cultivated Plants in South Africa. Durban, South Africa: Butterworths.

Bennett, R., S. Morse, and Y. Ismael. 2006. "The Economic Impact of Genetically Modified Cotton on South African Smallholders: Yield, Profit and Health Effects." Journal of Development Studies 42: 662-677.

Brookes, G. 2002. The Farm-Level Impact of Using Bt Maize in Spain. Brussels: EuropaBio.

Brookes, G., and P. Barfoot. 2008. GM Crops: Global Socio-Economic and Environmental Impacts 1996-2006. Dorchester, UK: PG Economics. 2010. GM Crops: Global Socio-Economic and Environmental Impacts 1996-2008. Dorchester, UK: PG Economics.

Fok, M., J. L. Hofs, M. Gouse, and J. F. Kirsten. 2007. "Contextual Appraisal of GM Cotton Diffusion in South Africa." Life Sciences International Journal 1 (4): 468-482. 
Gonzales, L.A. 2002. "Likely Transcendental Effects of Agribiotechnology: The Case of Bt Hybrid Corn in the Philippines." Paper presented during the Symposium on Bt Technology: Facts and Issues, May 5, Los Baños, Laguna, Philippines.

Gouse, M. 2009. "Ten Years of Bt Cotton in South Africa: Putting the Smallholder Experience into Context." In Biotechnology and Agricultural Development: Transgenic Cotton, Rural Institutions and Resource-Poor Farmers, edited by R. Tripp, 200-224. New York: Routledge.

Gouse, M., J. F. Kirsten, and L. Jenkins. 2003. "Bt Cotton in South Africa: Adoption and the Impact on Farm Incomes amongst Small-Scale and Large-Scale Farmers." Agrekon 42 (1): 15-28.

Gouse, M., J. F. Kirsten, and W. J. Van Der Walt. 2008. "Bt Cotton and Bt Maize: An Evaluation of Direct and Indirect Impact on the Cotton and Maize Farming Sectors in South Africa." Commissioned report to the Department of Agriculture: Directorate BioSafety, Pretoria, South Africa.

Gouse, M., J. Piesse, and C. Thirtle. 2006. "Output and Labour Effects of GM Maize and Minimum Tillage in a Communal Area of KwaZulu Natal." Journal of Development Perspectives 2 (2): 192-207.

Gouse, M., C. E. Pray, and D. E. Schimmelpfennig. 2004. "The Distribution of Benefits from Bt Cotton Adoption in South Africa." AgBioForum 7 (4): 187-194.

Gouse, M., B. Shankar, and C. Thirtle. 2008. "The Decline of Cotton in KwaZulu Natal: Technology and Institutions." In Hanging by a Thread: Cotton, Globalization, and Poverty in Africa, edited by W. G. Moseley and L. C. Gray, 103-120. Athens, OH, US: Ohio University Press.

Gouse, M., C. E. Pray, J. F. Kirsten, and D. E. Schimmelpfennig. 2005. "A GM Subsistence Crop in Africa: The Case of Bt White Maize in South Africa." International Journal of Biotechnology 7 (1-3): 84-94.

Gouse, M., C. E. Pray, D. E. Schimmelpfennig, and J. F. Kirsten. 2006. “Three Seasons of Subsistence Insect-Resistant Maize in South Africa: Have Smallholders Benefited?" AgBioForum $9(1): 15-22$.

Gouse, M., J. F. Kirsten, J. Piesse, C. Thirtle, and C. Poulton. 2010. "Insect Resistant and Herbicide Tolerant Maize Adoption by South African Smallholder Farmers-Making Sense of Seven Years of Research." Presented at the 14th International Consortium on Applied Bioeconomy Research conference, BioEconomy Governance: Policy, Environmental and Health Regulation and Public Investments in Research, June 16-18, in Ravello, Italy.

Hanekom, D. A. 2010. South African Deputy Minister of Science and Technology at launch of Biosafety South Africa, February 18, in Somerset Wes, South Africa. www.bizcommunity.com/ Article/196/148/45017.html.

Hofs, J. L., M. Fok, and M. Vaissayre. 2006. "Impact of Bt Cotton Adoption on Pesticide Use by Smallholders: A 2-Year Survey in Makhathini Flats (South Africa)." Crop Protection 25: 944-988. 
James, C. 2002. Global Review of Commercialized Transgenic Crops 2001: Feature Bt Cotton. Ithaca, NY, US: International Service for the Acquisition of Agric-Biotech Applications.

2007. Global Status of Commercialized Biotech/GM Crops: Brief 37-2007. Ithaca, NY, US: International Service for the Acquisition of Agric-Biotech Applications.

- 2009. Global Status of Commercialized Biotech/GM Crops: Brief 39-2009. Ithaca, NY, US: International Service for the Acquisition of Agric-Biotech Applications.

- 2010. Global Status of Commercialized Biotech/GM Crops: Brief 42-2010. Ithaca, NY, US: International Service for the Acquisition of Agric-Biotech Applications.

- 2011. Global Status of Commercialized Biotech/GM Crops: Brief 43-2011. Ithaca, NY, US: International Service for the Acquisition of Agric-Biotech Applications.

Marra, M. C., G. Carlson, and B. Hubbell. 1998. Economic Impacts of the First Crop Biotechnologies. Raleigh, NC, US: North Carolina State University.

Marra, M. C., P. G. Pardey, and J. M. Alston. 2002. "The Payoffs to Agricultural Biotechnology: An Assessment of the Evidence." Environment and Production Technology Division Discussion Paper 87. Washington, DC: International Food Policy Research Institute.

Qaim, M., E. J. Cap, and A. De Janvry. 2003. "Agronomics and Sustainability of Transgenic Cotton in Argentina." AgBioForum 6 (1-2): 41-47.

Republic of South Africa, Department of Science and Technology. 2001. National Biotechnology Strategy for South Africa. Pretoria. http://www.esastap.org.za/download/sa_biotechstrat_ jun2001.pdf.

Shankar, B., and C. Thirtle. 2005. "Pesticide Productivity and Transgenic Cotton Technology: The South African Smallholder Case." Journal of Agricultural Economics 56 (1): 97-115.

Tschirley, D., C. Poulton, and D. Boughton. 2006. The Many Paths of Cotton Sector Reform in Eastern and Southern Africa: Lessons from a Decade of Experience. International Development Working Paper 88. East Lansing, MI, US: Michigan State University.

Wolson, R. A., and M. Gouse. 2005. “Towards a Regional Approach to Biotechnology Policy in Southern Africa: Phase I, Situation and Stakeholder Analysis-South Africa." Food, Agriculture and Natural Resources Policy Analysis Network [FANRPAN] draft paper. Pretoria, South Africa: FANRPAN.

Woodburn, A. 1995. Cotton: The Crop and Its Agrochemicals Market. Balerno, Scotland: Allen Woodburn Associates / Managing Resources. 
